\title{
A Study On The Effects Of Nepotism, Favoritism And Cronyism On Organizational Trust In The Auditing Process In Family Businesses In Turkey
}

Hatice Necla Keleş, Bahcesehir University, Turkey

Tuğba Kıral Özkan, Bahcesehir University, Turkey Muhammet Bezirci, Selcuk University, Turkey

\begin{abstract}
Nepotism, favoritism and cronyism, which can be seen in all sectors of today's business world, have become quite common behavior. The granting of privileges to certain individuals is an extremely disturbing situation to the organization's employees and the lack of trust arising under such conditions negatively affects job satisfaction, organizational loyalty, and individual performance, and can hinder the internal control system in the auditing process. In this study, the effects of nepotism, favoritism and cronyism on organizational loyalty regarding the internal control system in the auditing process in the Turkish textiles sector are examined. In order to uncover the relationships in question, frequency breakdowns, Cronbach's Alpha reliability testing, and regression analysis are performed.
\end{abstract}

Keywords: Nepotism; Organizational Trust; Auditing; Internal Auditing

\section{INTRODUCTION}

f one examines the studies on family businesses, which are accepted as one of the important sources of economic development and growth (Olson et al., 2003), it is seen that they are generally for-profit social organizations created by individuals having kinship and business relationships with each other who come together to produce a product or service. In family businesses where family members hold effective positions, the family-member workforce's commitment to the organization is considered an important competitive advantage. But also, kindred employees are perceived not as persons having individual autonomy based on knowledge and skills, but rather as people under the protection of the family. To some, the expression "family business" means higher performance relative to large-scale enterprises, while to others it brings to mind certain drawbacks. Among these drawbacks are nepotism, generational conflicts, and capital problems (Mac Farlin, 2008). The notion of nepotism is used today in the broad sense for the recruitment of relatives to the same business (Ford and Mc Laughin, 1985). The recruitment, promotion or granting of privileged access to the organization's resources to persons lacking the necessary qualifications, but only based on their kinship and similar relationships, is thought to cause discontent, especially among the non-family employees (Arasli et al., 2006; Oren, 2007). Therefore, a lack of confidence in the people who are not family members can lead these people to consider themselves to belong to a different class. In turn, this can create the perception of favoritism in non-family employees (Ozler et al., 2007) and negatively affect the trust in the organization.

In this regard, some processes need to be performed in accordance with the standards of the work area in the auditing process of the businesses. One phase of this process is the auditing of the internal control mechanism. Internal control is steered by the board of directors, managers and employees of a business organization in order to ensure the effectiveness and efficiency of operations, the reliability of the financial reporting system, and regulatory compliance, and it is designed to provide reasonable assurance in this regard and defined as a system due to its place 
among business processes. According to the work area standards in the set of international auditing standards published by the International Auditing and Assurance Standards Board (IAASB), the examination of the internal control system is a requirement of the auditing process. The effects of the internal control system on the auditing process depend on the management's ability to create, implement, and manage the internal control standards. This is only possible with the existence of a corporate management. However, the phenomena of nepotism, favoritism and cronyism cause negativities during the institutionalization of businesses and hinder the business management's ability to manage this process well. The remainder of this study is organized as follows. In the next sections, the concepts of family businesses, nepotism, favoritism, cronyism, and organizational trust are examined based on the literature. The proposed hypotheses and methodology are presented in the next section, together with the sample, instruments and findings of the research. Finally, in the last section, a brief summary and concluding remarks are presented with a discussion of the results, limitations, and suggestions for future studies.

\section{LITERATURE REVIEW}

Family businesses are seen as important sources of economic development and growth (Olson et al., 2003). If one examines the studies on family businesses, it is seen that they are generally for-profit social organizations created by individuals having kinship and business relationships with each other who come together to produce a product or service. One or more family members are in effective positions in the management of family businesses. The commitment of the family-member work force to the organization and strong family ties are suggested as an important competitive advantage of the majority of these businesses. Also, rules and regulations necessary for the internal control system and set by the management are prepared

In addition to the internal control system as required by the management will be prepared within the framework of these family ties. Employees are seen not as persons having individual autonomy based on their knowledge and skills, but rather as people under the protection of the family. Therefore, the lack of trust in the persons who are not family members can cause these people to consider themselves to be in a different class. As a result, a perception of favoritism can emerge in the non-family employees (Ozler et al., 2007, 444). As for auditors, since misconduct and fraud in enterprises based on close kinships is less likely to occur (to be uncovered?), the impact of the internal control system in this regard needs to also be discussed. The term nepotism, derived from the Latin word Nepos meaning "nephew", is defined by Webster's Third New International Dictionary (MerriamWebster, 2000) as the appointment of nephews or other kin to duties based on relationships rather than qualifications. Nepotism is defined as an individual's attainment of recruitment, promotion, provision of more favorable working conditions and similar gains irrespective of their knowledge, abilities, skills, educational level, and experience but owing to their kinship ties (Ozsemerci, 2003). Favoritism is defined as the provision of special privileges to a friend, colleague or acquaintance in the areas of employment, career and personnel decisions (Merriam-Webster, 2000). Cronyism comes from the word crony, which originated as part of Cambridge University slang around the 1660s. Crony seems to have been intended to mean "friend of long-standing" (Dictionary of Word Origins, 1990). Cronyism appeared around 1840 and its original meaning was "the ability or desire to make friends." It came into use in political parlance when in 1952 the Truman administration was accused of appointing friends to government posts regardless of their qualifications. A journalist on the New York Times described this practice as cronyism, thus modifying the meaning of word (Oxford English Dictionary, 1989). Thereafter, the neutrality and innocence of the word was destroyed. With this change of meaning of cronyism, crony now often entails a derogatory sense of friendship with a trace of political corruption or preferential treatment about it (Khatri and Tsang, 2003).

Cronyism and favoritism are hard to control, especially in cultures that place a high value on interpersonal relations (http://www.citadel.edu/citadel), particularly to cronies, especially as evidenced in the appointment of political hangers-on to office without regard to their qualifications (Ashour, 2004).

According to others, nepotism, favoritism and cronyism are situations that eliminate or at least reduce firms' costs of employee search, selection and probing for talent (Ponzo, 2009; Bellow, 2003). According to this view, employees typically connect with people having skills similar to theirs. Hence, among job applications businesses give priority of recruitment to those referred by their highly productive employees, believing that in this way they can recruit persons with skills similar to the employees' (Montgomery, 1991). One of the negative effects 
of nepotism, favoritism, and cronyism on human resources management recruitment and placement practices is the fact that candidates are recruited due to their friendships and bold ties. Because these people may not have sufficient knowledge and qualifications for the job, they may not perform as well as other candidates that have appropriate qualifications. This causes unproductiveness on the part of other employees in the enterprise and can negatively impact organizational justice, motivation and harmony. Such impacts can cause productive employees to leave their jobs over time and to make comments about the institution to customers, colleagues and people around them which can harm the operation and image of the institution (Arasl and Tumer, 2008). A similar view is that nepotism will lead to low efficiency in auditing family-member employees. According to this view, the interwoven nature of the parent-child relationship will lead parent-owners of the business to biases and to make incorrect judgments in evaluating their own children (Lubatkin, 2005; Schulze et al., 2003; Schulze et al., 2001). This may cause audit reports to be far from reflecting the reality. The reason for this is that nepotism, favoritism and cronyism can affect the optimal preparation of the internal control system which constitutes the preparatory phase of the auditing process. This situation can have adverse effects on the efficacy of the auditing process. In nepotism, prevalent generally in family firms in many countries and which can be defined as the inter-generational transfer of management (Scoppa, 2009), when the founder of the business retires the control of the firm is typically handed over to the founder's heir instead of a business professional (Burkart, 2003; Bertrand and Schoar, 2006), which generally reflects the preferences of the founder who may sacrifice the firm's decision for the personal satisfaction from his or her own heir managing the enterprise. Despite this, the findings of many studies point to the fact that reduced performance occurs in firms that implement family inheritance of management (Perez-Gonzales, 2006). Many studies' results show that as negative sentiments toward the organization increase, the trust level of its employees decrease. Trust in the system is brought out by the written rules that the system community has and the determination of the rule-setting institutions in implementing them. Trust derives from the individual's belief that his or her rights will be protected by the system's written rules (Esmer, 1999). The word trust is defined in the Merriam-Webster Online Dictionary (2004) as "assured reliance on the character, ability, strength, or truth of someone or something."

In another definition organizational trust is indicated as the "employees' trust in the management and their degree of belief in what the management tells them." According to this definition, the source of organizational trust is the behavior of the upper-level and intermediate-level managers (Simsek and Tasci, 2004). Without organizational trust, the probability of the organization reaching its goals is either very low or nil. Trust is a basic human value that needs to be developed in every organization (Smith, 2005). Trust in an organization affects many variables such as individuals' job satisfaction, organizational justice, organizational commitment, organizational belonging, problem solving skills, risk-taking behavior, and creativity. Cook and Wall (1980) mention that the trust between individuals and groups is an important component of the organization's long-term profitability and the prosperity of the organization's members.

\section{RESEARCH HYPOTHESES}

Many studies point to the importance of trust inside an organization. In some of these studies it is observed that organizations having a higher level of trust are more successful, easily adaptable, and innovative relative to organizations with a lower level of trust.

Organizational trust is associated with all employees' job satisfaction and the organization's perceived effectiveness (Huff and Kelley, 2003), and it plays an important role in organizational activities and processes such as development of collaborative behavior, performance appraisal, goal setting, leadership, building of team spirit (McAllister, 1995; Jones and Geroge, 1998; Mayer et al., 1995), organizational commitment, and contribution to employee satisfaction (Huff and Kelley, 2003).

Cook and Wall's (1980) study arrives at the conclusion that there is a positive relationship between one's trust in coworkers and their job satisfaction. Different organizational structures affect the development of different formations of trust (Creed and Miles, 1996), and it is claimed that in the absence of trust, group members are less willing to show collaborative behavior (Henttonen and Blomqvist, 2005). Trust is a most fundamental, most effective, and most constructive factor regarding both intra-group dynamics and mutual relationships. In the absence of trust chronic suspicion prevails, leading individuals to beware of and avoid each other (Shaw, 1997). 
Along these lines of thought, the study aims to uncover the kind of relationship between nepotism, favoritism and cronyism in firms and the employee's perception of organizational trust. In parallel to the findings in the literature, we propose the following hypotheses:

Hypothesis 1: Nepotism has a significant negative effect on organizational trust in family firms. Hypothesis 2: Favoritism has a significant negative effect on organizational trust in family firms. Hypothesis 3: Cronyism has a significant negative effect on organizational trust in family firms.

\section{METHOD}

The survey method is used in this study via a questionnaire including a nepotism scale and an organizational trust scale together with demographic information. We analyze the data by simple linear regression for testing the hypotheses.

\section{PARTICIPANTS}

Data were collected using the convenience sampling method from 240 employees working in different units of family businesses in Istanbul. The sample consists of 55 females (22.9\%) and 185 males (77.1\%). The employee sample has ages between 19-56 years with a mean of 31.29 years. The educational levels of the sample is distributed as $14.6 \%$ having primary school education (35), $41.6 \%$ having high school education (100), 36.2\% having a university (undergraduate) degree (87), and 7.5\% having a master's degree (18). With respect to company size, $7.1 \%$ work at very small companies (1-9 employees), $8.3 \%$ work at small businesses (10-49 employees), $41.2 \%$ work at medium-size businesses (50-150 employees), and 43.3\% work at large-scale enterprises (151 or more employees).

\section{INSTRUMENTS}

The survey was implemented on non-kin-related employees of nine family businesses in the textiles industry in the Istanbul province. Company officials were contacted to be informed about the goal of the study, and the survey form was implemented on a total of 252 employees by pollsters. Of these survey forms, 240 suitable for analysis were taken into evaluation. Primarily, exploratory factor analysis results were examined for the construct validity of the scales and the Cronbach's Alpha value was examined for the survey's reliability.

\section{Nepotism, Favoritism and Cronyism Questionnaire}

Abdala et al (1998) developed this scale and it was translated into Turkish by Arasl and Tumer. The questionnaire consists of 25 questions with a 5-point Likert response scale. Factor analysis yields a KMO coefficient of 0.847 , which is greater than 0.7 and close to 1 , thus showing the suitability of the factor analysis. The Barlett test value is a significant $0.00(<0.05)$, validating the factor analysis. The scale consisting of 25 questions is grouped by the factor analysis under three dimensions, where the factor weights vary between 0.581 and 0.887 . The first dimension is nepotism, the second is favoritism, and the third is cronyism. The Cronbach's alpha value of the 25 expressions is 0.945 and the Cronbach's alpha values of each dimension are 0.855 for nepotism, 0.821 for favoritism, and 0.886 for cronyism.

\section{Organizational Trust Questionnaire}

This scale was introduced by Daboval, Comish, Swindle and Gaster (1994) and was translated into Turkish by Kamer (2001). The scale consists of three dimensions: personnel policies, superior-subordinate relationships, and communications. Each dimension contains 12 questions with a 5-point Likert-type scale, making a total of 36 questions. While it is known that the validity and reliability studies of this inventory were done by Daboval, Comish, Swindle and Gaster, their results are not available. However, in a reliability test by Kamer (2001) the Cronbach's alpha value was calculated as 0.966 . 
In the study, the factor analysis results for the organizational trust scale yield a KMO coefficient of 0.873 , which is greater than 0.7 and close to 1 , thus indicating the suitability of the factor analysis. The significance of the Barlett test $(\mathrm{p}=0.000)$ validates the factor analysis results. The scale consisting of 36 questions is grouped by the factor analysis under three dimensions, where the factor weights vary between 0.533 and 0.729 . The first dimension is superior-subordinate relationships, the second is communication, and the third is personnel policies. The Cronbach's alpha value of the 36 expressions is 0.939 and the Cronbach's alpha values of each dimension are 0.826 for superior-subordinate relationships, 0.751 for communication, and 0.766 for personnel policies. The organizational trust variable in the study is formed by 18 expressions subdivided into three dimensions.

\section{ANALYSIS}

We explore the effect of nepotism, favoritism and cronyism on organizational trust by simple linear regression. Simple regression analysis is done with the purpose of finding the power with which (the value of) an independent variable can explain the (value of the) dependent variable. In regression analysis, the ANOVA test reveals the validity of the model. If the ANOVA significance level is greater than 0.05 , the model is considered to be invalid, if it is smaller, it is then considered valid; i.e., the independent variable can successfully explain the dependent variable (Kalayci, 2006).

Prior to the regression analysis for each hypothesis, the normality and linearity assumption between the variables were checked and found not to be violated.

\section{RESULTS}

Hypothesis 1: Nepotism has a significant negative effect on organizational trust at in family firms.

The regression analysis results for the first hypothesis indicate a medium-level negative relationship between nepotism and organizational trust $(\mathrm{R}=0.675)$ and that nepotism can explain $45.5 \%$ of the variance of organizational trust $\left(\mathrm{R}^{2}=.455\right)$. Looking at the ANOVA values, there is no issue regarding the significance of the model's explanatory power $(\mathrm{F}=198.730, \mathrm{p}=0.000)$, as shown in Table 1 .

Table 1: Model Summary

\begin{tabular}{|c|c|c|c|c|c|c|}
\hline Model & $\mathbf{R}$ & $\mathbf{R}^{\mathbf{2}}$ & Adjusted R & Std. Error of Estimate & F & Sig. \\
\hline 1 & $.675(\mathrm{a})$ & .455 & .453 & .86995 & 198.130 & $.000(\mathrm{a})$ \\
\hline
\end{tabular}

a Predictors: (Constant), Nepotism

b Depent Variable: Organizational Trust

The estimated regression model parameters are all individually significant (at the 5\% significance level). The constant term is 5.695 and the nepotism coefficient is -0.807 . According to this, whenever there is a one unit increase in nepotism, there is a 0.807 unit decrease in organizational trust, as shown in Table 2.

Table 2: Coefficients

\begin{tabular}{|c|c|c|c|c|c|c|}
\hline \multirow{3}{*}{ Model } & & \multicolumn{2}{|c|}{ Unstandardized Coefficient } & Standardized Coefficient & & t \\
\cline { 2 - 7 } & & \multicolumn{2}{|c|}{ Std. Error } & Beta & 26,639 & .000 \\
\hline 1 & Constant & 5.695 & .214 & & $-14,099$ & .000 \\
\hline & Nepotism & -.807 & .057 & -.675 & -15 \\
\hline
\end{tabular}

The regression analysis results support the first hypothesis that "Nepotism has a significant negative effect on organizational trust." The coefficient values obtained by the regression analysis are depicted in Tables 1 and 2 .

Hypothesis 2: $\quad$ Favoritism has a significant negative effect on organizational trust in family firms. 
The results obtained for the second hypothesis indicate a medium-level negative relationship between favoritism and organizational trust $(\mathrm{R}=-0.609)$ and that favoritism can explain $37.1 \%$ of the variance of organizational trust $\left(\mathrm{R}^{2}=.371\right)$. Looking at the ANOVA values, there is no issue regarding the significance of the model's explanatory power $(\mathrm{F}=140.102, \mathrm{p}=0.000)$. The estimated regression model parameters are all individually significant. The constant term is 4.905 and the favoritism coefficient is -0.626 . According to this, whenever there is a one unit increase in favoritism, there is a 0.626 unit decrease in organizational trust. The regression analysis findings support the second hypothesis that "Favoritism has a significant negative effect on organizational trust."

Hypothesis 3: Cronyism has a significant negative effect on organizational trust in family firms.

For the third hypothesis, it is found that there is low-level negative relationship between cronyism and organizational trust $(\mathrm{R}=-0.365)$ and that cronyism can explain $13.3 \%$ of the variance in organizational trust $\left(\mathrm{R}^{2}=\right.$ .133). The ANOVA values indicate no issues regarding the significance of the model's explanatory power $(\mathrm{F}=36.645, \mathrm{p}=0.000)$. The estimated regression model parameters are all individually significant. The constant term is 4.108 and the cronyism coefficient is -0.383 . According to this, a one unit increase in cronyism results in a 0.383 unit decrease in organizational trust. The regression analysis findings support the third hypothesis that "Cronyism has a significant negative effect on organizational trust."

\section{CONCLUSION}

The aim of this study is to explore the effects of nepotism, favoritism and cronyism on the organizational trust in the auditing process in family businesses. The results of the study are in the hypothesized directions of nepotism, favoritism and cronyism being negatively related to organizational trust. The main finding of this study is that nepotism, favoritism and cronyism reduces organizational trust in family businesses.

In our review of the literature, we find that Lashinger and Finegan (2005) conclude that when the employee cannot access information on organizational decisions and actions and suspects that the information is confidential or is kept secret from the employee himself, his sense of trust in the management is lost. Singer and Tang (1996) state that distrust in the management leads to confrontations between employees and negatively affects individual performance. The results of Perez-Gonzales (2006) also agree with the body of literature arguing that in many situations, family ties and social connections lead to the recruitment of less-skilled personnel and cause the firm to display poor performance.

Although organizational trust is affected by nepotism, favoritism and cronyism in a structural model, this study also has some limitations. The observed relationship between the study variables is constrained by the selected sample. Obtaining more generalizable results requires comparing the existing results with qualitatively and quantitatively different samples.

The relationship between nepotism, favoritism and cronyism and organizational trust was identified in this study. Future research should focus on other organizational variables, such as performance, turnover, commitment, satisfaction and absenteeism, and should explore the relationship between nepotism, favoritism and cronyism and these variables.

\section{AUTHOR INFORMATION}

Hatice Necla Keles works as an assistant professor at Bahcesehir University, Istanbul, Turkey. She obtained her $\mathrm{Ph} . \mathrm{D}$. in Management and Organization Science in 2007. Her research is on the subjects of entrepreneurship, organizational intelligence, job satisfaction, and organizational commitment. E-mail: necla.keles@bahcesehir.edu.tr

Tugba Kıral Özkan is a lecturer at Bahcesehir University. She is currently working toward her doctoral degree in Operations Research in the Econometrics department at Marmara University, Istanbul, Turkey. Her focus is on the subjects of entrepreneurship, organizational intelligence, multivariate statistics, and structural equation models. Out of her working time, she deals with photography and has participated in group photography exhibitions. E-mail: tugba.kiral@bahcesehir.edu.tr 
Muhammet Bezirci has obtained his doctorate degree in accounting and finance in 2003. He currently works as an assistant professor at Selcuk University, Konya, Turkey. He also holds a public accountant certificate. He has studies on auditing, risk analysis, cost analysis, and R\&D incentives. E-mail: mbezirci@ selcuk.edu.tr

\section{REFERENCES}

1. Arasl1, H., Bavik, A. \& Ekiz, E.H. (2006). "The Effects of Nepotism on Human Resource Management, The Case of threei four and five star hotels in Northern Cyprus", International Journal of Sociology and Social Policy, 26,7, 295-308.

2. Arasl, H. and Tumer, M.(2008), "Nepotism, Favoritism and Cronyism: A Study of Their Effects on Job Stress and Job Satisfaction in the Banking Industry of North Cyprus, Social Behavior and Personality, Vol.36, No:9,pp.1237-1250.

3. Ashour, A. S. (2004). Transparency and accountability in the public sector in the Arab region, Concept paper 3, United Nations. Available from: www.unpan1.un.org/intradoc/groups/public/documents/un/unpan015390.pdf

4. Bertrand, M. \& Schoar, A. (2006), "The role of family in family firms", Journal of Economic Perspectives, Vol.2, pp.73-96.

5. Burkart, M., Panunzi, F.and Shleifer, A. (2003). "Family firms”, Journal of Finance, Vol.58, No.5, 21672201.

6. Cook, J. ve T. Wall (1980), "New Work Attitude Measures Of Trust, Organizational Commitment And Personal Need Non-Fulfillment", Journal of Occupational Psychology, 53, 39-52.

7. Creed, W. M. and Miles, R. E. (1996), “Trust in organization: A Conceptual Framework Linking Organizational Forms, Managerial Philosophies and the Opportunity Cost of Control" in Kramer, R. M. and Tyler, T. E. (Eds), Trust in Organization: Frontiers of Theory and Research, Thousand Oaks, CA:Sage, 16-38.

8. Daboval, J., Comish, R., Swindle, B. \& Gaster, w. (1994) A Trust

9. Esmer, Y.(1999), Devrim, Evrim, Statüko:Türkiye'de Sosyal, Siyasal ve Ekonomik Değerler, TESEV Yayınları, No:7, Istanbul.

10. Ford, R. \& Mc Laughin, F. (1985). "Nepotism”, Personnel Journal, 64, 57-61.

11. Hettonen, K. ve K. Blomqvist (2005), "Managing Distance In A Global Virtual Team: The Evlotion Of Trust Through Technology-Mediated Relational Communication", Strategic Change, 14, 107-119.

12. Huff, L. ve L. Kelley (2003), "Levels of Organizational Trust in Individualist Versus Collectivist Societies: A Seven Nation Study", Organization Science, Vol 14:1.

13. Kalaycı, Ş. (2006), SPSS Uygulamalı Çok Değişkenli İstatistik Teknikleri, Ankara: Asil Yayınları.

14. Khatri, N.\& Tsang W.K. (2003), "Antecedents and Consequences of Cronyism in Organizations", Journal of Business Ethics, 43, 289-303.

15. Lashinger, K.S.H ve J. Finegan (2005), "Using Empowerment to Build Trust and Respect in the Workplace: A Strategy for Addressing the Nursing Shortage", Nursing Economics, 23:1.

16. Mayer, R., Davis J.H.Ve F.D Schoorman (1995), “Integration Model Of Organizational Trust”, Academy of Management Review, Vol 20:3.

17. McAllister, D.(1995), “Affect And Cognition Based Trust As Foundations For Interpersonal Cooperation In Organization", Academy Of Management Journal, 38:1 ,24-59

18. Mc Farlin, B. D. (2008), “Does Family Matter to Corporate Performance?”, Academy of Management Perspectives, May, 100-101.

19. Merriam-Webster Online Dictionary, available at: www.m-w.com/cgibin/dictionary?bbook=Dictionary \&va=Trust $\& x=12 \& y=3$ (accessed 17 December 2004)

20. Montgomery, J. (1991), "Social networks and labor market outcomes: toward an economic analysis", American Economic Review, Vol.81,No: 5, pp.1407-1418.

21. Olson, P.D., Zuiker, V.S., Danes, S. M., Stafford, K., Heck R. K. and Duncan K.A. (2003). "The Impact of the Family and the Business on Family Business Sustainability", Journal of Business Venturing, 18, 5, 639666.

22. Ören, K.(2007). “Sosyal Sermayede Güven Unsuru ve İşgücü Performansına Etkisi”, Kamu-İş, Cilt:9 Say1:1,71-90. 
23. Özsemerci, K. 2003. Türk kamu yönetiminde yolsuzluklar, nedenleri, zararları ve çözüm önerileri. Sayıştay Araştırma/ İnceleme/ Çeviri Dizisi, Ankara.

24. Özler, H., Ergun, D. Ö. \& Gümüştekin, G.E. (2007). “Aile İşletmelerinde Nepotizmin Gelişim Evreleri ve Kurumsallaşma”, Selçuk Üniversitesi Sosyal Bilimler Enstitüsü Dergisi, 17, 437-450.

25. Polat, S.(2009), Örgütsel Güven, Pegem Akademi, Ankara.

26. Ponzo, M. and Scoppa,V.(2010), "The use of informal networks in Italy: Efficiency or favoritism?", Journal of Socio-Economics, Vol. 39, No.1, pp 89-99.

27. Rosenblatt, P. C., De Mik, L., Anderson, R.M.\& Johnson, P. (1995).The Family in Business, Jossey-Bass Publishers, San Francisco, California.

28. Schulze, W., Lubatkin, M.H., Dino, R., \& Buchholtz, A. K.(2001), “Agency relationship in family firms: Theory and evidence", Organization Science, Vol.12, pp.99-116.

29. Shaw, R.B. (1997), "Trust in Balance: Building Successful Organizations on Results, Integrity and Concern", Jossey-Boss Publishers, San Francisco

30. Singer, M.G.\& Tang, T.L.P. (1996). Factors Related To Perceived Organizational Instrumentality, Journal of Collective Vnegotiations in the Public Sector, 25, 271-286.

31. Smith, G. (2005), "How to achieve organizational trust within an accounting department", Managerial Auditing Journal, Vol.20, No.5, pp.520-523.

32. SSimşek, S. \& Alptekin T. (2004). "Örgütlerde "Güven" Konsepti Ve Emniyet

33. Örgütü'nde Güven Modellerinin Değerlendirilmesi". Polis Dergisi, S:34, ss.1

34. http://www.citadel.edu/citadel 